\title{
Impacts of climate change on forest product markets: Implications for North American producers
}

\author{
by Brent Sohngen ${ }^{1}$ and Roger Sedjo 2
}

\begin{abstract}
This paper examines potential climate change impacts in North American timber markets. The results indicate that climate change could increase productivity in forests in North America, increase productivity in forests globally, and reduce timber prices. North American consumers generally will gain from the potential changes, but producers could lose welfare. If dieback resulting from additional forest fires, increased pest infestation, or storm damage increases appreciably and has market effects, consumers will gain less and producers will lose more than if climate change simply increases the annual flow of timber products by raising forest productivity. Annual producers' surplus losses from climate change in the North American timber sector are estimated to range from $\$ 1.4-\$ 2.1$ billion per year on average over the next century, with the higher number resulting from potential large-scale dieback. Within North America, existing studies suggest that producers in northern regions are less susceptible to climate change impacts than producers in southern regions because many climate and ecological models suggest that climates become dryer in the U.S. South.
\end{abstract}

Key words: climate change, impact analysis, timber markets, forest ecosystems

\section{RÉSUMÉ}

Cet article examine les effets potentiels associés aux changements climatiques sur les marchés du bois en Amérique du Nord. Les résultats démontrent que les changements climatiques pourraient accroître la productivité des forêts de l'Amérique du Nord, accroître la productivité des forêts à l'échelle mondiale et réduire les prix de la matière ligneuse. Les consommateurs nord-américains bénéficieront en général des changements potentiels, mais les producteurs pourraient encourir des pertes. Suite à la mortalité découlant des feux de forêts plus nombreux, de l'accroissement des infestations de ravageurs ou des dégâts provoqués par des tempêtes augmentant de façon appréciable, les consommateurs connaîtrons moins de bénéfices et les producteurs verront leurs pertes s'accroitre si les changements climatiques accroissent simplement le volume annuel de produits forestiers suite à l'accroissement de la productivité. Les pertes annuelles pour les producteurs sont estimées être en 1,4 à 2,1 milliards de dollars par années au cours du prochain siècle, le montant supérieur résultant d'une forte mortalité à grande échelle. En Amérique du Nord, les études laissent entendre que les producteurs des régions nordiques connaîtront moins d'effets suite aux changements climatiques que les producteurs du sud parce que plusieurs modèles climatiques et écologiques suggèrent que le climat deviendra plus sec dans le sud des États-Unis.

Mots clés : changements climatiques, analyses des effets, marchés du bois, écosystèmes forestiers

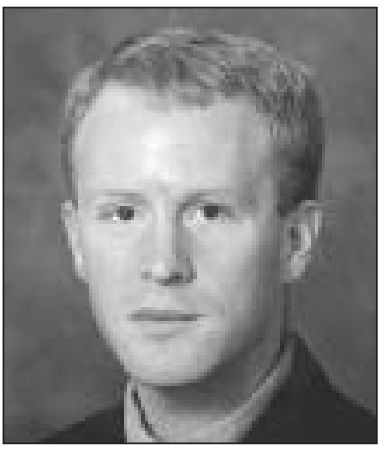

Brent Sohngen

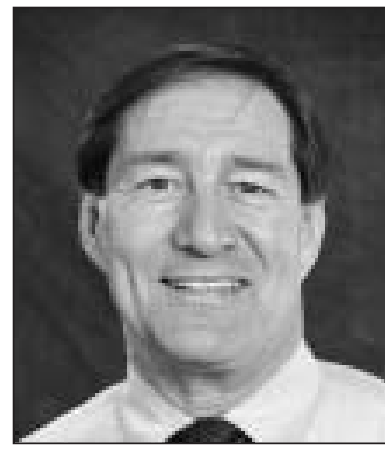

Roger Sedjo

\section{Introduction}

It is widely recognized that climate change will have substantial impacts upon forested ecosystems during this century (McCarthy et al. 2001). In addition to many existing stresses, such as deforestation, pest infestations, forest fires, and invasive species, climate change is expected to increase stresses upon forested ecosystems. These stresses include potential changes in the distribution of species (Iverson and Prasad 2001), positive or negative changes in the productivity of individual species and entire ecosystems (Shugart et al. 2003), potential increases in storm damage or forest fires due to changes in climate and weather patterns (Dale et al. 2001).

\footnotetext{
${ }^{1}$ AED Economics, Ohio State University, 2120 Fyffe Rd., Columbus, OH 43210-1067, USA. E-mail: Sohngen.1@osu.edu

${ }^{2}$ Resources For the Future, 1616 P. St., NW, Washington DC 20036, USA. E-mail: sedjo@rff.org
} 
The ecological impacts of climate change could have substantial impacts on North American timber markets. The largest temperature changes this century are anticipated to occur in higher latitude regions (McCarthy et al., 2001). A large proportion of forest biomass stock resides in northern Canada, and changes in these stocks could have consequences in markets. Furthermore, some climate change scenarios suggest that productivity in the U.S. South could decline, at least for a time (VEMAP Members 1995, Joyce et al. 2001). The U.S. South currently produces a large proportion of total timber in the U.S., so any reduction could have large implications for prices.

Forestry is an important component of the North American natural resource base. In regions like the Southern United States, or British Columbia, forestry contributes heavily to the local industrial base. Forest products are also an important export product for Canada in particular. Currently, the value of forest products exports from Canada are around $\$ 40$ Billion, or $9 \%$ of total exports for the country (Statistics Canada 2005). Canada supplies approximately $30 \%$ of the U.S. lumber market (Haynes 2003). Any changes in the productivity of forests could have long-term consequences for the forest products industry in both countries.

This paper explores the potential economic impacts of climate change upon the forest products industry of Canada and the U.S. We begin with a review of the literature exploring the range of studies that have been conducted to analyze potential impacts. We then present and discuss the results of several analyses of potential climate change impacts estimated for the United States, where most research has been conducted on economic impacts, in more detail. Finally, we examine the results of the global analysis in Sohngen et al. (2001) more closely, presenting specific results for North America. The final section of the paper presents our conclusions.

\section{What Ecological Impacts are Important for Measuring the Market Impacts?}

In order to assess the potential market impacts of climate change in forestry, several important ecological effects must be considered. The ecological effects generally fall into two categories: stock effects and flow effects. Stock effects are those that influence existing timber stands. These include dieback effects that result from storm damage, forest fires, pest infestations, and other disturbances not caused by harvesting trees. Forests have always been susceptible to natural disturbance patterns, and current forest conditions are a result of past disturbances. To the extent that climate change influences the spatial pattern, the pace, or the intensity of future disturbance patterns, the existing stock of forests could be directly susceptible to climate change. Flow effects are different. For the purposes of this paper, we consider flow effects to be the influence of climate change on the annual growth of trees. Changes in precipitation and temperature, or enhanced $\mathrm{CO}_{2}$ in the atmosphere are all factors that can affect the annual growth of trees.

It is often difficult to distinguish between stock and flow effects, particularly when moving from smaller spatial scales to more aggregated scales. At the level of a stand, individual tree mortality is a stock effect. At the level of a region, mortality among individual trees can be measured as a reduction in net growth, and therefore individual tree mortality can be viewed as a flow effect. Larger events such as catastrophic for- est fires, large-scale bug infestations, mortality from winter ice storms, etc., however, could be viewed as stock effects. To the extent that these stock effects are large enough to have market implications (i.e., by spurring salvage logging and reducing prices for a time) it is important to account for them as stock effects rather than as flow effects when measuring economic impacts.

From the ecological literature, there is widespread acknowledgement that both stock and flow effects can be important. The recent Canadian National Assessment (Lemmen and Warren 2004) and U.S. National Assessment (Joyce et al. 2001) of climate change impacts refer widely to the importance of both effects. The Canadian National Assessment, for instance, suggests that growth in forests in northern Ontario and the western part of the country could increase, while growth in the Great Lakes and St. Lawrence areas could decrease. The U.S. National Assessment by contrast, suggests that forest growth in most regions is likely to increase in the future.

Both the Canadian National Assessment and the U.S. National Assessment report that there could be large increases in most disturbance regimes, including forest fires, insect infestations, and storm damage. Neither of the reports are specific about the actual sizes of changes that might occur in disturbance patterns, or their impacts upon forests, but the U.S. National Assessment report does provide telling detail on projections of potential changes in forest fire regimes. That report suggests that fire severity in the U.S. could increase up to $10 \%$ during climate change and that the area burned could increase $25 \%$ to $50 \%$. As noted by Dale et al. (2001), the new disturbance regimes introduced by climate change could have substantial and sustained impacts upon forest regimes in the U.S.

When economic models are developed, they often utilize data on tree yields for different age classes to estimate empirical yield functions. These are net yield functions that account for historical disturbances within the forests, and historical climate trends. They are the baseline yield functions. Accounting for climate change requires adjusting these functions to incorporate the impact of climate change on forest growth (flow effects), and/or exogenously perturbing the stock of forests to capture potential effects on the forest stock (stock effects).

Within the literature, two basic approaches have been used to model climate change impacts. First, a number of studies have assumed only flow effects (Joyce et al. 1995, Perez-Garcia et al. 1997, Irland et al. 2001). These studies link projected changes in yields of forest types from ecological models directly to the net yield functions used in the economic model. These models do not assume stock effects are occurring, or at least they assume that the stock effects occur over a small enough area that they have little impact on near-term market outcomes. The ecological models may allow for individual tree mortality when calculating changes in annual tree growth, but this individual tree mortality is assumed to be small enough that it does not have market level effects.

Second, some studies have assumed both flow and stock effects (Sohngen and Mendelsohn 1998, 2001; Sohngen et al. 2001). These studies link projected changes in yields of forest types directly to net yield functions used in the economic model. They also account for potentially large stock effects that influence forest stands available for harvest in early periods of the model simulation. Since some trees can be market- 
ed even after they have "died" in these scenarios, the modellers usually assume some proportion of the value of the forest is salvaged when dieback occurs.

One of the most important questions remaining in climate change analysis of impacts upon forests is the issue of carbon fertilization. Current evidence indicates that additional $\mathrm{CO}_{2}$ in the atmosphere could increase forest productivity, but it is unclear whether this will increase overall net ecosystem productivity (Shugart et al. 2003). Some trees could grow more quickly, some more slowly, and others could experience additional mortality. Modeling studies that allow for carbon fertilization tend to show substantial increases in net primary productivity and overall forest area relative to studies with the same climate change conditions, but without the carbon fertilization effects (VEMAP Members 1995). For the most part, the economic studies conducted to date have assumed carbon fertilization occurs and they have used the modeled predictions of carbon fertilization either on net primary productivity or total carbon to assess potential flow, or yield, effects.

Before considering the economic impacts of climate change on markets, it is important to note that while climate change is a global phenomena that clearly requires global action to slow down or prevent, all impacts are local. Estimating economic impacts in forestry requires having information on the regional ecological impacts, at a minimum. Currently, estimates of regional climate change are much more variable across climate models than even the highly variable aggregate estimates of climate sensitivity. Without more refined estimates of climate change impacts at the regional level, it will remain difficult to precisely pin down economic impacts for producers in specific regions. Future research will clearly refine existing results as newer models do a better job of accounting for regional impacts.

\section{Review of Market Impact Studies in North America}

Before reviewing the studies that have examined the economic impacts of climate change, it is useful to define several terms used to describe these impacts in monetary terms. Net surplus is a term that represents the monetary value (in U.S. \$ for example) of market activity as measured by consumers' surplus plus producers' surplus. Consumers' surplus measures economic impacts of climate change upon consumers. It is a measure of the monetary benefits of market activity to individuals consuming products made from timber. In general, consumers surplus will increase if timber prices decline due to climate change. Producers' surplus is a measure of the monetary benefits producers obtain by participating in the market for timber products. For the studies described in this paper, producers' surplus represents economic profits landowners obtain from holding and managing their forest land. The economic effects of climate change are measured by comparing consumers' plus producers' surplus in the baseline case without climate change, to consumers' plus producers' surplus with climate change. In general, if climate change makes forests more productive, then timber prices will fall, consumers will benefit (and consumers' surplus will increase) and producers will lose (producers' surplus will decline). The opposite occurs if climate change makes forests less productive.

A number of studies have estimated the market impacts of climate change in the U.S. Few economic estimates for Canada have been produced, although the global models examined in the next section do present results for Canada.
For the U.S., economic studies indicate that net surplus (consumers' plus producers' surplus) is likely to increase (Joyce et al. 1995; Sohngen and Mendelsohn 1998, 2001; Irland et al. 2001; Shugart et al. 2003). Consumers gain the most in the scenarios because forest growth is generally expected to increase over the next century, resulting in more timber being available for markets. Producers, however, lose in most cases because prices decline. While most studies project increased timber yields, these gains are not strong enough to offset the lower prices.

Within the U.S., the most vulnerable region appears to be the South. For temperature changes of $1.5^{\circ}$ to $5^{\circ} \mathrm{C}$ for the U.S. as a whole, Sohngen and Mendelsohn (2001) estimate that net surplus in timber markets increases by $13 \%$ to $25 \%$. Net surplus in the U.S. South and Pacific Northwest, however, is projected to decline $1 \%$ to $20 \%$. Producers' surplus in these two regions is projected to decline by $11 \%$ to $43 \%$. Results from Irland et al. (2001) suggest smaller overall economic impacts for the U.S. $(0.05 \%$ to $0.18 \%$ changes in net surplus over the coming century). One reason that the impacts in the Irland et al. (2001) study are smaller than those in Sohngen and Mendelsohn (2001) is that Irland et al. (2001) assume no changes in species distribution. Sohngen and Mendelsohn (2001) allow landowners to adjust species from one type to another when climate changes, and in particular, they allow southern species to expand northward, thereby increasing economic productivity in the North.

The studies by Sohngen and Mendelsohn $(1998,2001)$ also suggest the importance of accounting for potential largescale dieback effects. One of their scenarios considers the possibility that the area of forests killed by fires increases by approximately 700000 hectares each year for 70 years (a $41 \%$ increase in total area burned each year assuming baseline burning of 1.7 million hectares). Dieback is assumed to kill all trees on sites where it occurs, although it is also assumed that $75 \%$ of the value of the forests could be salvaged. Dieback such as this has two major economic implications. First, dieback can be large enough to influence prices in the near term. The loss of stock suppresses producers' surplus in regions where dieback is largest. Second, to avoid future losses from additional dieback, producers need to adjust the species they plant for the new climate conditions. If producers can regenerate "optimally" for the new and changing climate, they can avoid future damages and avoid additional negative impacts. If, however, they make mistakes in the types of species they plant by planting timber types that are susceptible to additional dieback effects, producer losses will increase (see Sohngen and Mendelsohn, 1998).

\section{North American Impacts Derived from a Global Model}

To date, there have been relatively few global studies of the impacts of climate change in timber markets. Perez-Garcia et al. (1997) utilized the CINTRAFOR Global Trade Model to estimate impacts of flow effects in global forests, while Sohngen et al. (2001) utilized a dynamic optimization model and analyzed flow and stock effects. The ecological model used in Perez-Garcia et al. (1997) considers only productivity changes and not potential dieback effects. Under the climate and productivity scenarios they examined, nearly all regions experience increased productivity in softwoods and hardwoods, although productivity in some Southeast Asian hardwoods is projected to decline. As a result, Perez-Garcia et al. 
(1997) suggest that climate change will cause softwood and hardwood production in the U.S. and Canada to increase. Canada in particular, is projected to obtain $20 \%$ to $30 \%$ increases in softwood production over the next 50 years. While net surplus is projected to increase in both countries, the benefits are largest for the U.S.

The study by Sohngen et al. (2001) examines both stock and flow effects by combining the ecological implications of the BIOME3 model (Haxeltine and Prentice 1996) for two climate scenarios with a dynamic optimization model of global timber markets. Two climate scenarios used in this analysis are the Hamburg T-106 model (Claussen 1996) and the UIUC model (Schlesinger et al. 1997). Both models project equilibrium climate for a baseline and a scenario with doubled $\mathrm{CO}_{2}$ conditions. The UIUC model is more sensitive to doubled $\mathrm{CO}_{2}$, simulating a larger global temperature change of $3.4^{\circ} \mathrm{C}$ versus $1^{\circ} \mathrm{C}$ for the Hamburg model. The regional effects in the models differ. For instance, the Hamburg model predicts larger temperature changes in high latitude regions compared to the UIUC model.

Across the two climate scenarios, North American forests undergo more dieback in general than forests in other regions of the world: $28 \%$ to $29 \%$ compared to $6 \%$ to $14 \%$ for nonNorth American regions (see Sohngen et al. 2001 for a full discussion of the ecological and economic results). The yields of North American forests also increase less than in other regions ( $17 \%$ versus $32 \%$ to $42 \%$ ), and the net expansion in forests is only $3 \%$ to $4 \%$ versus $19 \%$ to $28 \%$ in the rest of the world. While North America appears to gain productivity and forest area, it gains less than the rest of the world, and under the dieback scenarios it is projected to experience more dieback than other regions. To put the dieback scenarios into context, the area of North American forests that dies back due to climate change each year is approximately 1.6 million hectares. Current estimates suggest that approximately 4.2 million hectares of forest land burn each year in Canada and the U.S. in the baseline ( 1.7 million hectares per year in the U.S. and 2.5 million hectares per year in Canada), suggesting that climate change could increase this by $38 \%$ relative to the baseline.

The change in timber production for timber types in North America under the regeneration and dieback scenarios is shown in Fig. 1a and 1b. The results are averaged for the two climate scenarios and presented for the dieback and regeneration alternatives. The results indicate that timber production in North America could decline by 54 million $\mathrm{m}^{3}$ per year on average if climate change causes dieback during the period 1995-204533. Without dieback, i.e., under the regeneration scenarios, timber production in North America could expand by 30 million $\mathrm{m}^{3}$ per year on average over the same time period. Forests in the northern conifer and mountain west regions appear to be the most susceptible to climate change impacts, as production declines in those regions under both dieback and regeneration. Southern forest types expand northward, and therefore suggest gains for that type.

\footnotetext{
${ }_{3}^{3}$ Average annual baseline production is expected to be relatively constant over the century in North America, at 530 million m3 per year. This change, therefore, represents an $11 \%$ reduction in timber harvests.
}

The global effects of climate change on timber production for additional timber producing regions of the world are shown in Fig. 2a and 2b. The regions shown account for around $90 \%$ of global timber production and consumption. As with the results for North America alone, the global results for both dieback and regeneration show that long-term gains in timber production are expected, but dieback can reduce these gains initially. In these scenarios, North America and Russia are the most susceptible regions between 2000 and 2050 because they experience the greatest overall dieback. Europe, on the other hand, benefits from the dieback scenarios because dieback is not projected to have strong effects there. Production in Europe rises relative to the baseline in the period 2010-2030, and offsets the reductions in North America and Russia. European production subsequently declines to baseline levels during the period 2040-2070 in the dieback scenario as a result of these strong earlier harvests.

Perhaps more importantly for producers in North America, production in South America and Oceania is projected to expand substantially in the period 2000-2030 in the dieback scenario. South America shows strong and growing gains in production under dieback throughout the century. Little dieback is projected there, and producers can quickly adjust short rotation species that dominate timber markets as climate changes. As a consequence, these scenarios indicate that producers in emerging industrial forestry regions like South America could potentially benefit substantially during climate change.

When translated into economic impacts, these results imply that producers' surplus in North America could decline by $\$ 1.4$ to $\$ 2.1$ billion per year over the next century. Producers lose surplus under the regeneration scenario because prices decline, but the losses are approximately $30 \%$ smaller because existing mature stocks are not lost each year. Despite the losses to producers in the dieback scenarios, consumer's surplus is positive because prices fall. These falling prices result from increases in timber production that occurs in other regions of the world that gain relative to the North America.

Developing countries uniformly fare the best under the climate change scenarios examined in Sohngen et al. (2001). Developing countries tend to be in tropical and subtropical regions, and they tend to focus on shorter rotation species. These short rotation species provide multiple opportunities for more rapid adaptation to the ecological and economic effects of climate change, i.e., rising productivity and lower overall prices. As a consequence, the share of global timber production from South America is anticipated to increase $8 \%$ to $13 \%$ over the next century under climate change.

\section{Conclusion}

This paper examines the potential economic implications of climate change in North America. Climate change could have substantial impacts on forests by altering the growth of trees, causing dieback in forests, and by causing species to migrate. Given that the largest initial effects of climate change are anticipated to occur in high latitude regions, like Canada, and given the important trade relationship between the two countries in forestry, it is important to carefully assess the implications of climate change impacts for the entire North American region. 


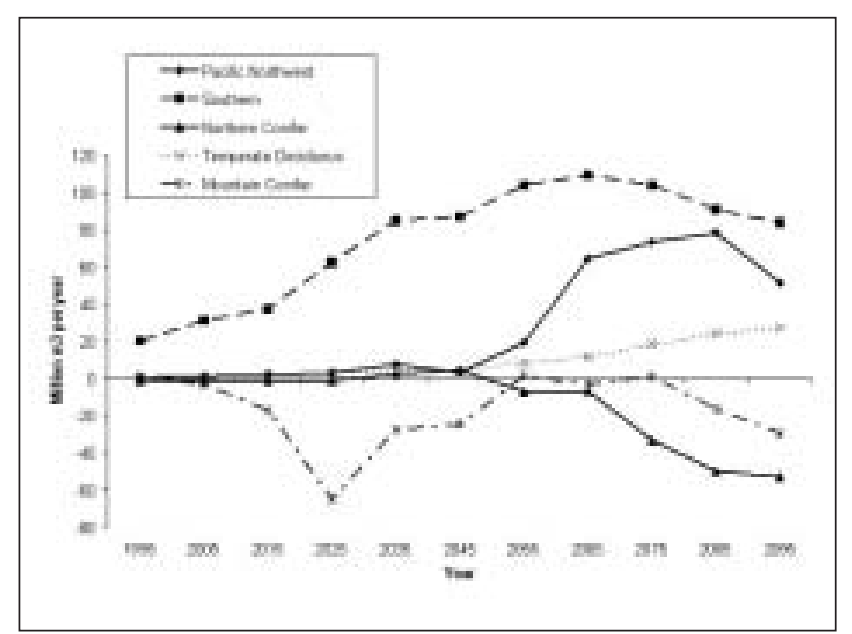

Fig. 1a. Comparison of timber harvests under dieback for North American timber types.

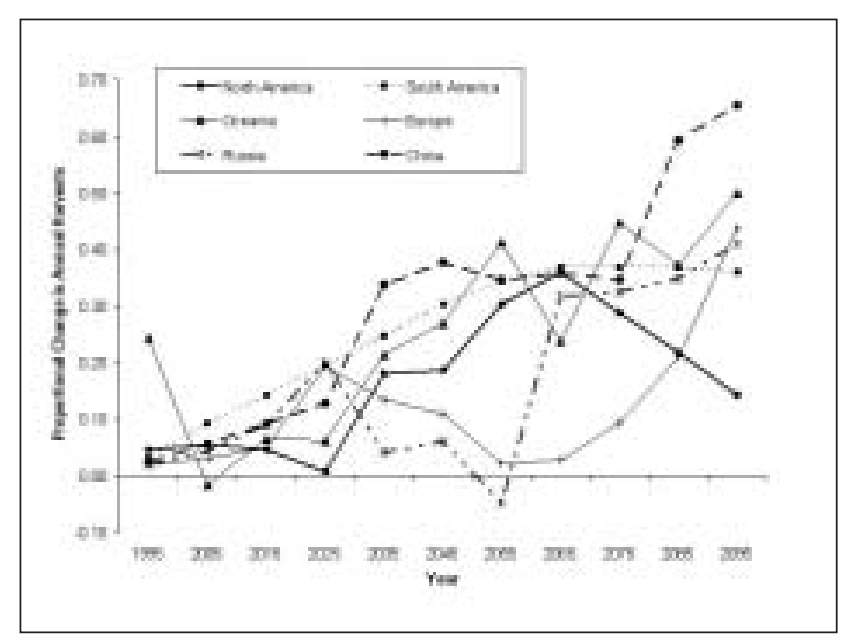

Fig. 2a. Comparison of timber harvests under dieback and regeneration scenarios for selected regions around the world. Proportional change in timber harvests for selected regions under the Regeneration Scenario.

The paper begins by examining the potential influence of climate change on forests. The effects of climate change are considered in two categories, flow effects and stock effects. Flow effects adjust the potential future growth of forests due to climate change, and potential carbon fertilization. Stock effects influence current forests through disturbance mechanisms such as forest fires, pest infestations, or windthrow. While flow effects can have potentially large implications for long-term economic outcomes by affecting the future growth of forests, stock effects can have potentially important nearterm impacts by altering supply conditions relatively quickly.

The most extensive analysis of the potential economic impacts of climate change have been conducted in the U.S. to date. The results of these studies suggest that climate change will generally benefit markets in the U.S. because climate change will increase the productivity of forests and enhance the long-term supply of timber. Most of these benefits, however, accrue to consumers. Producers' surplus tends to decline

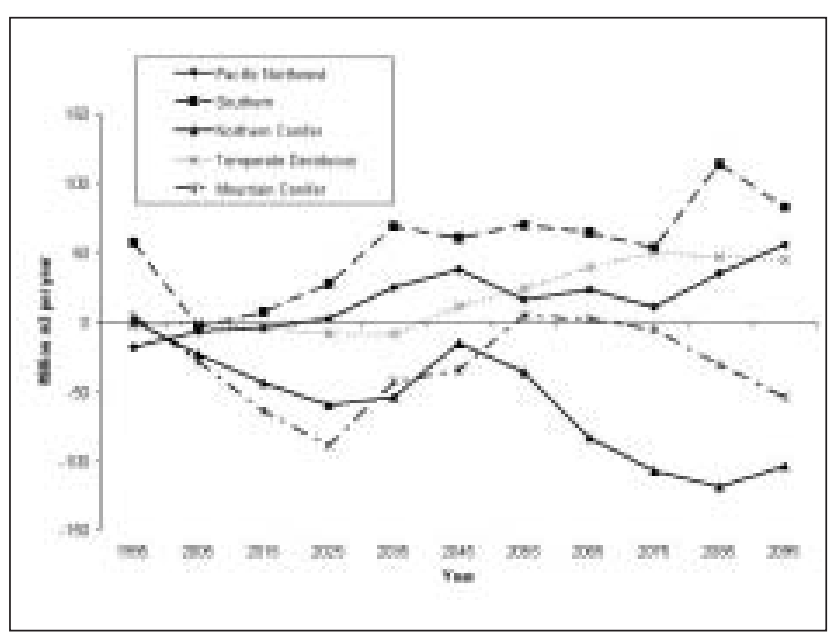

Fig. 1b. Comparison of timber harvests under dieback for North American timber types.

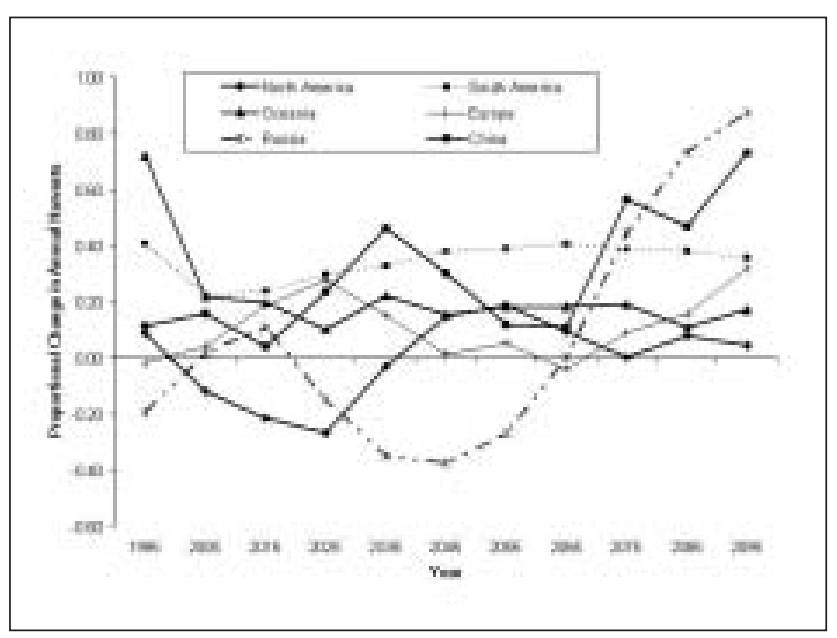

Fig. 2b. Comparison of timber harvests under dieback and regeneration scenarios for selected regions around the world. Proportional change in timber harvests for selected regions under the Dieback Scenario.

when prices fall. In general, the U.S.-based studies indicate that producers in northern regions tend to gain surplus while those in southern regions could lose surplus.

One limitation of many of the studies conducted in the U.S. to date is that they have mostly ignored the ecological and economic implications of global change. That is, they have excluded price effects caused by climate change that occurs in competing regions of the world. The paper reviews recent studies by Perez Garcia et al. (1997) and Sohngen et al. (2001) who take a more careful look at these global impacts. The results of the study by Sohngen et al. (2001) for North America are specifically compared and contrasted with results from the same study for different regions.

North America appears to be susceptible to climate change both for ecological and economic reasons. On the ecological side, the ecological model used in the analysis by Sohngen $e t$ al. (2001) indicates that North America could experience relatively larger dieback effects under that scenario, leading to 
losses of production relative to the baseline during the period 1995-2045. For the case of North America, the dieback scenarios imply that the area of forests that burns each year increases from 4.2 million hectares to 5.8 million hectares, or a 38\% increase. Regions that experienced less dieback tend to gain producer surplus when dieback occurs elsewhere. The absence of dieback however, does not necessarily benefit producers. Lower prices caused by expanding production have broadly negative effects on producers throughout the temperate, developed regions.

In contrast to the developed countries, developing countries mainly appear to benefit from climate change. Many developing countries are located in climates optimally suited to cultivating fast-growing timber plantations. These regions have been gaining global market share in recent years, and these trends are expected to be strengthened during climate change. For example, South American producers are estimated to gain $8 \%$ to $13 \%$ market share during climate change, with larger gains if dieback occurs in temperate regions.

The review of the literature conducted in this paper and the analysis developed with the results from Sohngen et al. (2001) suggest several important future research directions. First, the economic results are heavily influenced by regional climate change and ecological estimates. Since climate models are still highly aggregated, and methods for regionalizing the large-scale general circulation models are still rudimentary, it will be important to re-assess the economic results as newer data become available. Second, the economic results are sensitive to potential dieback effects. Some authors have chosen to ignore potential dieback, or to model dieback by linking modeled yield changes to net changes in ecosystem productivity (Joyce et al. 1995, Perez-Garcia et al. 1997, Irland et al. 2001). Others have accounted for dieback as a direct stock effect (Sohngen and Mendelsohn 1998, 2001; Sohngen et al. 2001). Given the potentially important influence of dieback on the results in these last studies, and given the emphasis in recent literature on potential dieback effects (Joyce et al. 2001, Lemmen and Warren 2004), more careful integrated ecological-economic analysis of potential stock effects should be conducted. Third, as demonstrated in PerezGarcia et al. (1997) and Sohngen et al. (2001), it is important to capture global effects when estimating local economic impacts. It will be important in future economic modeling exercises to have access to consistent global analyses of potential climate change impacts on ecosystems.

\section{Acknowledgements}

We appreciate comments from Tim Williamson in writing this paper. Funding for this research obtained from the US Department of Energy, Climate Change Research Division; US Environmental Protection Agency STAR grant; US Environmental Protection Agency, Climate Analysis Branch.

\section{References}

Claussen, M. 1996. Variability of global biome patterns as a function of initial boundary conditions in a climate model. Climate Dynamics. 12: 371-379.

Dale, V.H., L.A. Joyce, S. McNulty, R.P. Neilson, M.P. Ayres, M.D. Flannigan, P.J. Hanson, L.C. Irland, A.E. Lugo, C.J. Peterson, D. Simberloff, F.J. Swanson, B.J. Stocks and B.M. Wotton. 2001. Climate change and forest disturbances. BioScience. 51(9): 723-734.
Haxeltine, A. and I.C. Prentice. 1996. BIOME3: An equilibrium terrestrial biosphere model based on ecophysiological constraints, resource availability, and competition among plant functional types. Global Biogeochemical Cycles. 10(4): 693-709.

Haynes, R. 2003. An analysis of the timber situation in the United States: 1952-2050. U.S. Department of Agriculture, Forest Service, Pacific Northwest Research Station, General Technical Report, PNW-GTR-560. Portland, OR.

Irland, L., D. Adams, R. Alig, C.J. Betz, C. Chen, M. Hutchins, B. A. McCarl, K. Skog and B.L. Sohngen. 2001. Assessing socioeconomic impacts of climate change on U.S. forest, wood-product markets, and forest recreation. Bioscience. 51(9): 753-764.

Iverson, L.R. and A.M. Prasad. 2001. Potential changes in tree species richness and forest community types following climate change. Ecosystems. 4(3): 186-199.

Joyce, L. J. Aber, S. McNulty, V. Dale, A. Hansen, L. Irland, R. Neilson and K. Skog. 2001. Potential consequences of climate variability and change for the forests of the United States. In National Assessment Synthesis Team (eds.). Climate change impacts in the United States: the potential consequences of climate variability and change $(\mathrm{Ch}$. 17). Cambridge University Press, Cambridge, U.K.

Joyce, L.A., J.R. Mills, L.S. Heath, A.D. McGuire, R.W. Haynes and R.A. Birdsey. 1995. Forest sector impacts from changes in forest productivity under climate change. Journal of Biogeography. 22: 703-713.

Lemmen, D.S. and F.J. Warren. 2004. Climate change impacts and adaptation: a Canadian perspective. Natural Resources Canada. Canadian National Government.

McCarthy, J.J., O.F. Canziani, N.A. Leary, D.J. Dokken and K.S. White. 2001. Climate change 2001: impacts, adaptation, and vulnerability. Cambridge University Press, Cambridge, UK.

Perez-Garcia, J., L.A. Joyce, A.D. McGuire and C.S. Binkley. 1997. Economic impact of climatic change on the global forest sector. In R.A. Sedjo, R.N. Sampson and J. Wisniewski (eds.). Economics of carbon sequestration in forestry. Lewis Publishers, Boca Raton, FL.

Schlesinger, M.E., N. Andronova, A. Ghanem, S. Malyshev, T. Reichler, E. Rozano, W. Wang and R. Yang. 1997. Geographical scenarios of greenhouse-gas and anthropogenic-sulfate-aerosol induced climate changes. Un-numbered Publication, Climate Research Group, Department of Atmospheric Sciences, University of Illinois at Urbana-Champaign.

Shugart, H., R. Sedjo and B. Sohngen. 2003. Forests and global climate change: potential impacts on U.S. forest resources. Pew Center on Global Climate Change.

Sohngen, B. and R. Mendelsohn. 1998. Valuing the market impact of large scale ecological change: the effect of climate change on US timber. American Economic Review. 88(4): 689-710.

Sohngen, B. and R. Mendelsohn. 2001. Timber: ecological-economic analysis. In R. Mendelsohn (ed.). Global warming and the American economy: a regional assessment of climate change impacts (Ch. 4). Edward Elgar, Northhampton, MA.

Sohngen, B., R. Mendelsohn and R. Sedjo. 2001. A global model of climate change impacts on timber markets. Journal of Agricultural and Resource Economics. 26(2): 326-343.

Statistics Canada. 2005. http://www.statcan.ca/start.html

VEMAP Members. 1995. Vegetation/Ecosystem modeling and analysis project (VEMAP): comparing biogeography and biogeochemistry models in a continental scale study of terrestrial ecosystem responses to climate change and $\mathrm{CO}_{2}$ doubling. Global Biogeochemical Cycles. 9: 407-437. 